УДК 66.03:665.5.06, 615.322:664.59, 663.937

DOI https://doi.org/10.15673/swonaft.v84i1.1873

\title{
ІННОВАЦІЙНІ ПРОЦЕСИ ОДЕРЖАННЯ ФІТОЕКСТРАКТІВ I КОНЦЕНТРАТІВ ДЛЯ ХАРЧОВОЇ, ФАРМАЦЕВТИЧНОЇ ТА ПАРФУМЕРНО-КОСМЕТИЧНОЇ ПРОМИСЛОВОСТІ
}

\author{
Терзісв С.Г., д-р техн. наук, доцент, Ружицька Н.В., канд. техн. наук, асистент, \\ Сиротюк І.В., аспірант, Акімов О.В., аспірант, Щербич М.В., аспірант \\ Одеська національна академія харчових технологій
}

\begin{abstract}
Анотація. В роботі розглядаються шляхи одержання фітоекстрактів з різних груп рослинної сировини для харчової, фармацевтичної та парфумерно-косметичної промисловості з використанням інноваційних технологій адресної доставки енергії.

В якості об 'єктів досліджень розглянуто ефіроолійну сировину: лаванду, м'яту периеву, квітки троянди та шипшини; фруктово-ягідну - сливові вичавки, та відходи кавового виробництва - кавове лушпиння. Наведено иляхи використання фітоекстрактів з розглянутої сировини у харчовій, фармацевтичній та парфумерно-косметичній промисловостях. Визначено основні перспективні для вилучення компоненти.

В якості механізму, який дозволяє підвищити ефективність екстрагування цільових компонентів з розглянутої рослинної сировини розглядається бародифузія, яку ініціює мікрохвильове поле. НВЧелектромагнітні хвилі виступають засобом адресної доставки енергї до мікро- та наноструктурструктур сировини. Для збереження термолабільних сполук у фітоекстрактах пропонується комбінування бародифузї з кипінням екстрагенту в умовах вакууму. Розглядається конструкиія мікрохвильового вакуумекстрактора.

Розглянуто перспективи створення нових технологічних ліній переробки ефіроолійної сировини на основі нового мікрохвильового обладнання. Наведено дані по зразкам продуктів, одержаних за запропонованою технологією. При переробці лаванди та м'яти перцевої окрім екстрактів одержано ефірну олію та гідролати. Під час екстрагування фруктово-ягідної сировини вилучено ло 42\% сухих речовин.

Показано вплив мікрохвильового підведення енергї̈ на вихід сухих речовин з лушпиння. Наведено результати з дослідження кінетики вилучення сухих речовин з сировини при різних режимах екстрагування. В результаті екстрагування кавового лушпиння у запропонованому інноваційному екстракторі одержано екстракти з високим вмістом кофеїну.
\end{abstract}

Ключові слова: екстрагування, бародифузія, ефіроолійна сировина, фруктово-ягідна сировина, кавове лушпиння

\section{INNOVATIVE PROCESSES OF OBTAINING PHYTOEXTRACTS AND CONCENTRATES FOR THE FOOD, PHARMACEUTICAL, PERFUME AND COSMETICS INDUSTRIES}

\author{
Terziyev S.H., Doctor of Engineering Science, Associate Professor, \\ Ruzhytska N.V., PhD, assistant, Syrotyuk I.V., postgraduate student, \\ Akimov O.V., postgraduate student, Shcherbych M.V., postgraduate student \\ Odessa National Academy of Food Technologies
}

\begin{abstract}
In current paper the ways of obtaining phytoextracts from various groups of plant raw materials for the food, pharmaceutical and perfume and cosmetics industries using innovative technologies of targeted energy delivery are considered.

As objects of research essential oil raw materials: lavender, peppermint, rose and rosehip flowers; fruit and berry - plum pomace, and coffee production waste-coffee husks were considered. Ways of using phytoextracts from the analyzed raw materials in the food, pharmaceutical, perfume and cosmetics industries are presented. The main promising components for extraction are identified.

Barodiffusion initiated by a microwave field is considered as a mechanism that makes it possible to increase the efficiency of extraction of target components from the studied plant raw materials. Microwave electromagnetic field acts as a means of targeted energy delivery to micro- and nanostructures of raw materials. To preserve
\end{abstract}


Одеська національна академія харчових технологій

\section{ЕНЕРГОЕФЕКТИВНІСТЬ. РЕСУРСОЗБЕРІГАЮЧІ ТА ЕКОЛОГІЧНО-БЕЗПЕЧНІ}

ЕНЕРГОТЕХНОЛОГІЇ

thermolabile compounds in phytoextracts, it is proposed to combine barodiffusion with extractant boiling under vacuum conditions. The design of a microwave vacuum extractor is considered.

Prospects of creating new technological lines for processing essential oil raw materials based on new microwave equipment are given. Data on samples of products obtained using the proposed technology are presented. When processing lavender and peppermint, in addition to extracts, essential oil and hydrolates were obtained. During the extraction of fruit and berry raw materials, $42 \%$ of dry matter were extracted.

The effect of microwave energy supply on the yield of dry matter from the coffee husk is shown. The results of studying the kinetics of dry matter extraction from raw materials under various extraction modes are presented. As a result of extracting coffee husks in the proposed innovative extractor, extracts with a high caffeine content were obtained.

Key words: extraction, barodiffusion, essential oil raw materials, fruit and berry raw materials, coffee husks

Вступ. Рослинна сировина є джерелом широкого спектру біологічно активних речовин: вітамінів, органічних комплексів мікроелементів, вітаміноподібних речовин, пігментів, глікозидів, терпенів та терпеноїдів, олій. Фітоектсракти в харчовій промисловості використовуються як для збагачення продуктів мікронутрієнтами, так і для надання кольору, смаку та аромату. У фармацевтичній та парфумерно-косметичній галузях рослинні екстракти виступають головним чином як діючі або допоміжні компоненти.

Об'єкти досліджень. Дослідження проводились з різними групами рослинної сировини, а саме ефіроолійною, фруктово-ягідною та відходами виробництва кави. 3 ефіроолійної сировини обї'єктами було обрано лаванду, м'яту та троянду - рослини, які вирощуються в Україні.

Лаванда $€$ цінною ефіроолійною сировиною. Екстракти лаванди, які містять ефірну олію та дубильні речовини, мають антимікробну та ранозагоювальну дію і використовуються у лікарських засобах таких, як, наприклад, «Судокрем», «Рятівник» і різноманітних косметичних засобах $[1,2]$. В останній час відстежується тенденція додавання екстрактів лаванди та інших ефіроолійних рослин у молочні продукти (Danone botanicals, TM «Простоквашино»- Кефір на ніч»).

Троянда $є$ сировиною для одержання дорогої ефірної олії. В той же час екстракти пелюсток троянди та шипшини використовуються у косметичних засобах [3]. В них містяться флавоноїди, білки, вуглеводи, вітаміни, ефірна олія. 3 пелюсток, и особливо, кошиків вилучають нелеткі смолисті речовини, які мають властивості фіксатору ароматів [4]. Є дані про антимікробні властивості екстрактів квіток шипшини [5]. Екстракти троянди знаходять застосування у виробництві напоїв (TM Buvette, FUZETEA). За антиоксидантною активністю екстракти квіток не поступаються зеленому чаю, і характеризуються високим вмістом антоціанів та галової кислоти [6].

М'ята широко використовується у виробництві напоїв, кулінарії, фармації. Ефірна олія м'яти - цінна сировина для парфумерно-косметичної галузі та виробництва широкого спектру лікарських препаратів $[1,7]$. Також з м'яти вилучаються полі фенольні сполуки і флавоноїди [8-10]. В листі також містяться вільні жирні кислоти (лінолева, ліноленова, пальмітинова), стероїди, ксантофіли, хлорофіл, каротиноїди, $\alpha$-токоферол, аскорбінова кислота, вітамін Р, алкалоїди $[7,10]$.

Серед відходів харчових виробництв привертає увагу кавове лушпиння. Серед сучасних шляхів переробки даного відходу запропоновано: одержання біопалива, живильних субстратів для культивування грибів, комбікормів для риб, виробництво добрив, а також вилучення біологічно активних компонентів. У кавовому лушпинні міститься $8 \ldots 11 \%$ білка, до $3 \%$ ліпідів, $58 . . .85 \%$ вуглеводів, в тому числі порядку $12 \%$ цукрів, близько $1 \%$ кофеїну і $5 \%$ танінів [11]. У світі кавове лушпиння розглядається як сировина для виготовлення напоїв (чаї), пряних сумішей, виробництва харчових волокон, одержання кофеїну [12].

3 фруктово-ягідної сировини в якості об’єкта досліджень було обрано відходи - вичавки, екстракти 3 яких містять барвні речовини (переважно антоціани), вітаміни, віск, органічні кислоти. Такі екстракти можуть використовуватись в якості натуральних барвників і ароматизаторів у харчових виробництвах.

Формулювання завдань досліджень. При екстрагуванні біологічно активних компонентів з рослинної сировини, температура та тривалість процесу є одними з основних факторів, що впливають на якість кінцевого продукту, оскільки більшість сполук і, особливо, вітаміни, термолабільні [13]. Враховуючи високу вартість ефіроолійної та кавової сировини ставиться задача найбільш ефективного ії використання і збільшення виходу найбільш цінних продуктів при зменшенні питомих витрат енергії на виробництво.

Відомо, що ініціювання явища бародифузії у наноструктурах рослинної сировини в наноструктурах рослинної сировини дозволяє значно зменшити тривалість процесу екстрагування [14] i, відповідно, дію високих температур на термолабільні компоненти.

Явище бародифузії виникає, коли в мікро- і нанокапілярах рослинної сировини під дією мікрохвильового поля утворюються осередки пароутворення. В результаті тиск у структурі різко зростає і відбувається руйнування стінок клітини або капіляра і вихід цільових компонентів у дифузійне середовище $[14,15]$. При 
такій організації процесу стає можливим перехід до екстрагенту нерозчинних в ньому речовин, які можуть утримуватись в розчині у вигляді різноманітних колоїдних систем.

Найбільш вдалим способом підведення енергії до продукту для ініціювання бародифузії є мікрохвильовий, оскільки НВЧ-електромагнітні хвилі діють безпосередньо на воду або інші полярні речовини в сировині, викликаючи їх нагрівання, таким чином здійснюючи адресну доставку енергії $[14,15]$.

Турбулізація потоку екстрагенту також забезпечує постійний контакт свіжих порцій екстрагента 3 твердою фазою. Інтенсифікації процесу екстрагування за рахунок перемішування можна досягти за допомогою мішалок, барботерів, проте таке обладнання конструктивно важко виконати у мікрохвильовому апараті. Іншим шляхом є створення умов для кипіння екстрагента за низьких температур. Цей принцип здійснюється у мікрохвильовому вакуум-екстракторі, конструкція екстрактора наведена на рис. 1.

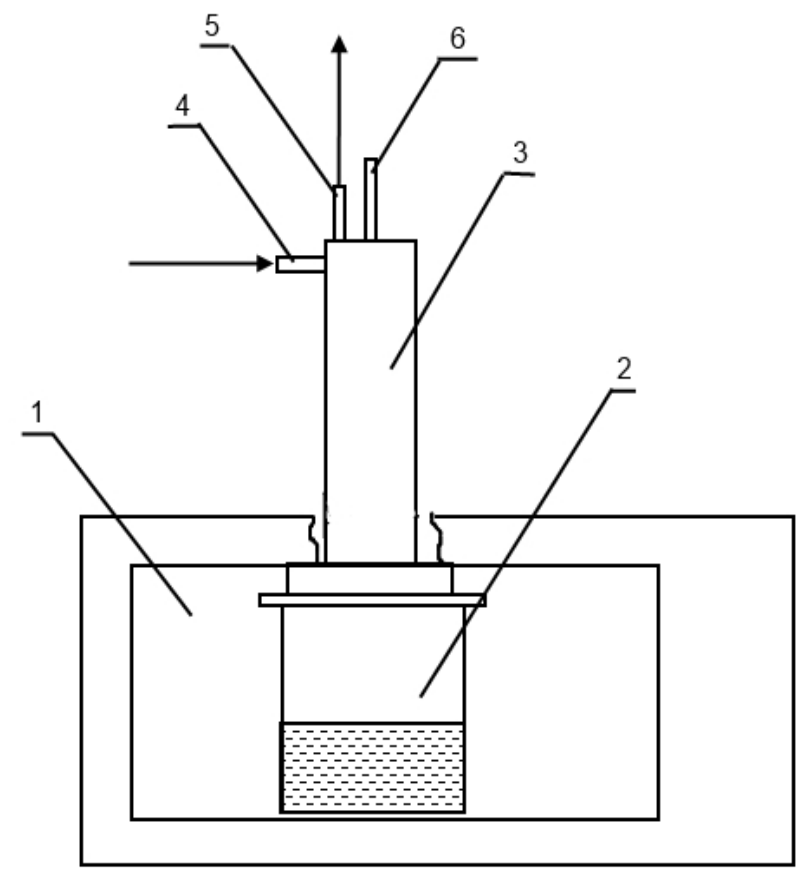

1 -мікрохвильова камера; 2 - герметична радіопрозора ємність з продуктом; 3 - конденсатор; 4 - патрубок надходження холодного теплоносія; 5 - патрубок відведення відпрацбованного холодного теплоносія; 6 - патрубок відведення повітря з ємності з екстрагентом

Рис. 1 - Схема мікрохвильового вакуум-экстрактора

Впровадження принципово нового екстракційного обладнання із адресною доставною енергії дозволяє запропонувати нові схеми переробки ефіроолійної та іншої нетрадиційної сировини, зкоротивши кількість технологічних операцій. Блок-схема переробки ефіроолійної сировини на прикладі лаванди із застосуванням мікрохвильового екстракційного та дистиляційного обладнання наведено на рис. 2.

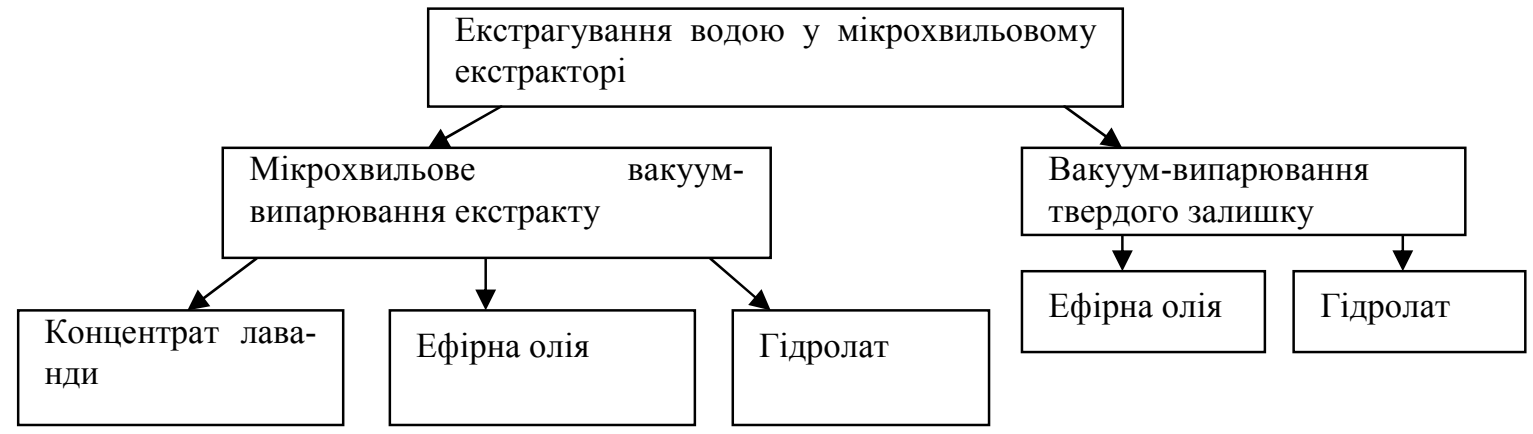

Рис. 2 - Схема переробки ефіроолійної сировини із застосуванням мікрохвильового обладнання 
Одеська національна академія харчових технологій

\section{ЕНЕРГОЕФЕКТИВНІСТЬ. РЕСУРСОЗБЕРІГАЮЧІ ТА ЕКОЛОГІЧНО-БЕЗПЕЧНІ} ЕНЕРГОТЕХНОЛОГІЇ

У випадку переробки іншої рослинної сировини у запропонованій схемі буде відсутня операція одержання ефірної олії. В той же час для лікарських трав, фруктових вичавок, відходів кавового виробництва отримання гідролату лишається актуальним процесом, оскільки даний продукт є цінною сировиною для парфумерно-косметичної промисловості.

За даною схемою одержано екстракт лаванди - мутну рідину коричневого кольору. Після осадження та фільтрування твердих часток, прозорості розчину досягти не вдалося, що вказує на перебування частини компонентів в екстракті у вигляді емульсії. Причиною такого результату може бути бародифузія, коли в потік екстрагенту з капілярів разом із парою захоплюються нерозчинні в даному екстрагенті речовини. Схожі процеси відбуваються при паровій дистиляції ефірних олій.

При концентруванні екстракту в якості побічного продукту одержали ефірну олію лаванди та гідролат 3 характерним ароматом.

Вміст сухих речовин в концентратах лаванди в середньому склав близько 40 \%. Температура екстрагування не перевищувала $80{ }^{\circ} \mathrm{C}$, дистиляції - $96^{\circ} \mathrm{C}$. За аналогічною схемою переробки одержано екстракт, гідролат та ефірну олію м'яти зі свіжої, в'яленої та сушеної сировини.

Сухі пелюстки троянди екстрагували водою в мікрохвильовому екстракторі при температурах $80-90{ }^{\circ} \mathrm{C} 3$ гідромодулем 1:12. В екстракт перейшло $18 \%$ від маси вихідної сировини. Одержано екстракт рожевого кольору з характерним ароматом троянди і фруктовими нотками. Аналогічний продукт одержано 3 пелюсток шипшини. Також одержано спиртовий екстракт кошиків троянди, який містить віски та смоли, що мають властивості фіксаторів аромату і входять до складу абсолюті троянди. В мікрохвильовому вакуумекстракторі вилучено до 10 \% сухих речовин від маси вихідної сировини і одержано концентрат - в'язку рідину темного зелено-коричневого кольору з вмістом сухих речовин 18\%. Температура процесу складала $66-70^{\circ} \mathrm{C}$

При переробці плодово-ягідних відходів одержано екстракт вичавок сливи при температурі $66^{\circ} \mathrm{C}$ i $3 а$ тиску 32 кПа. До екстракту перейшло 42\% від маси вихідної сировини. Після концентрування в мікрохвильовій вакуум-випарній установці одержано концентрат з вмістом сухих речовин 20,5\% 3 вираженим фруктовим смаком та ароматом з горіховими нотками, темно-червоного кольору.

Результати екстрагування розглянутої ефіроолійної та плодово-ягідної сировини в мікрохвильовому вакуум-екстракторі наведено у таблиці 1.

Таблиия 1

Результати екстрагування рослинної сировини в мікрохвильовому вакуум-екстракторі

\begin{tabular}{|l|l|c|c|c|}
\hline Продукт & Екстрагент & Температура, ${ }^{\circ} \mathrm{C}$ & $\begin{array}{l}\text { Тривалість } \\
\text { обробки, хв }\end{array}$ & $\begin{array}{l}\text { \% від маси вихідної } \\
\text { сировини, що пе- } \\
\text { рейшов до екстрак- } \\
\text { ту }\end{array}$ \\
\hline $\begin{array}{l}\text { Екстракт пелюсток } \\
\text { троянди }\end{array}$ & Вода & 80 & 40 & 18 \\
\hline $\begin{array}{l}\text { Екстракт кошиків тро- } \\
\text { янди }\end{array}$ & Етанол, 96\% & 70 & 80 & 10 \\
\hline Екстракт вичавок сливи & Вода & 66 & 50 & 42 \\
\hline
\end{tabular}

При дослідженні процесу вилучення компонентів кавового лушпиння водою встановлено вихід сухих речовин при екстрагуванні з використанням традиційного та мікрохвильового підведення енергії. Результати наведено в таблиці 2.

Таблиия 2

Вихід сухих речовин $з$ кавового лушпиння

\begin{tabular}{|c|c|c|cc|}
\hline Тип установки & Екстрагент & Температура, ${ }^{\circ} \mathrm{C}$ & $\begin{array}{l}\text { Загальна кількість екстрактивних } \\
\text { речовин, \% }\end{array}$ \\
\hline Водяна баня & Вода & $70-75$ & \multicolumn{2}{|c|}{18,4} \\
\hline МХ-вакуум-екстрактор & Вода & $70-75$ & 24,4 \\
\hline
\end{tabular}

Встановлено, що при однакових температурах вихід сухих речовин з лушпиння в умовах мікрохвильового підведення енергії на $6 \%$ вище. (рис. 3).

Для визначення раціональних режимів обробки було проведено досліди з вичерпання твердої фази 


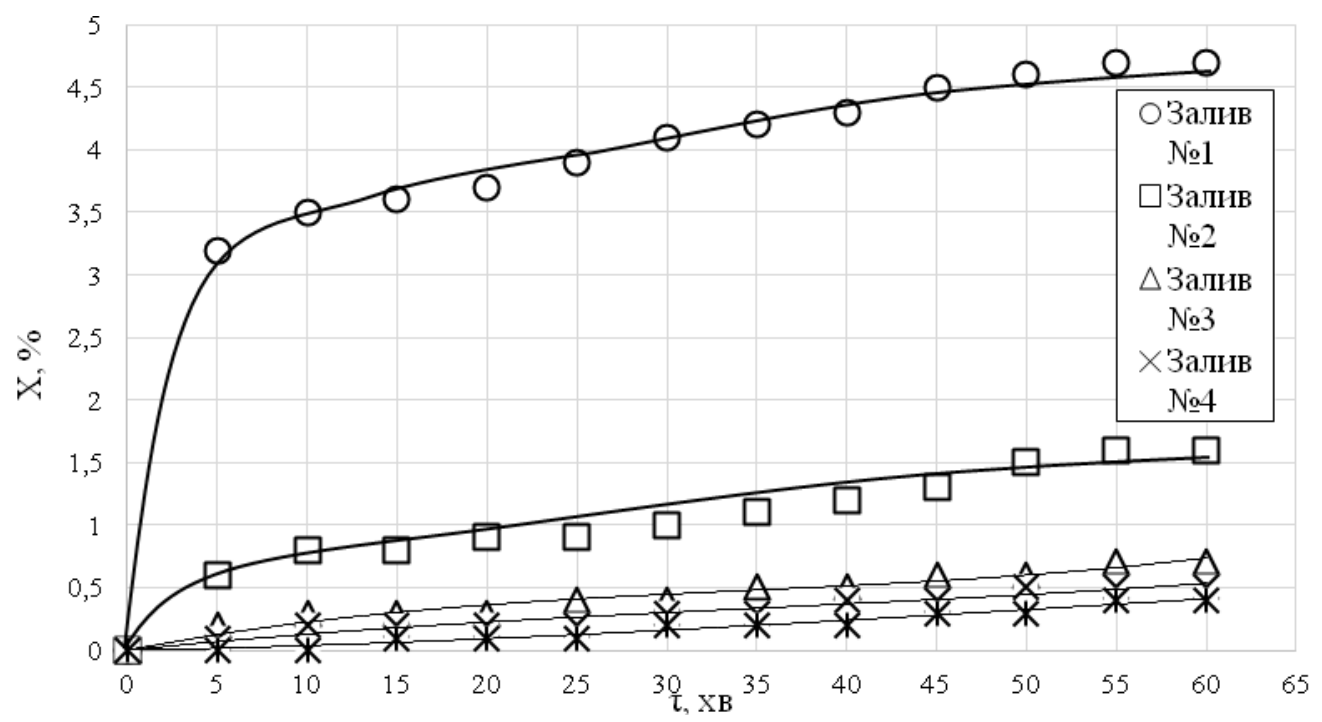

Рис. 3 - Зміна концентрації в часі для кожного заливу (МХ-екстрактор)

Як видно з графіків, найбільший відсоток сухих речовин вилучається в перші 60 хвилин роботи при першому заливі. Вилучено близько 60 \% всіх екстрактивних речовин. 3 другим заливом вилучили 20 \% від можливого. Після другого заливу вилучення сухих речовин зменшується з 10 до 4\%. Ці дані дозволяють підібрати раціональні режими екстрагування та доекстрагування.

Проведено порівняння кінетики екстрагування з кавового лушпиння при традиційному підведенні енергії і в умовах дії мікрохвильового поля (рис. 4).

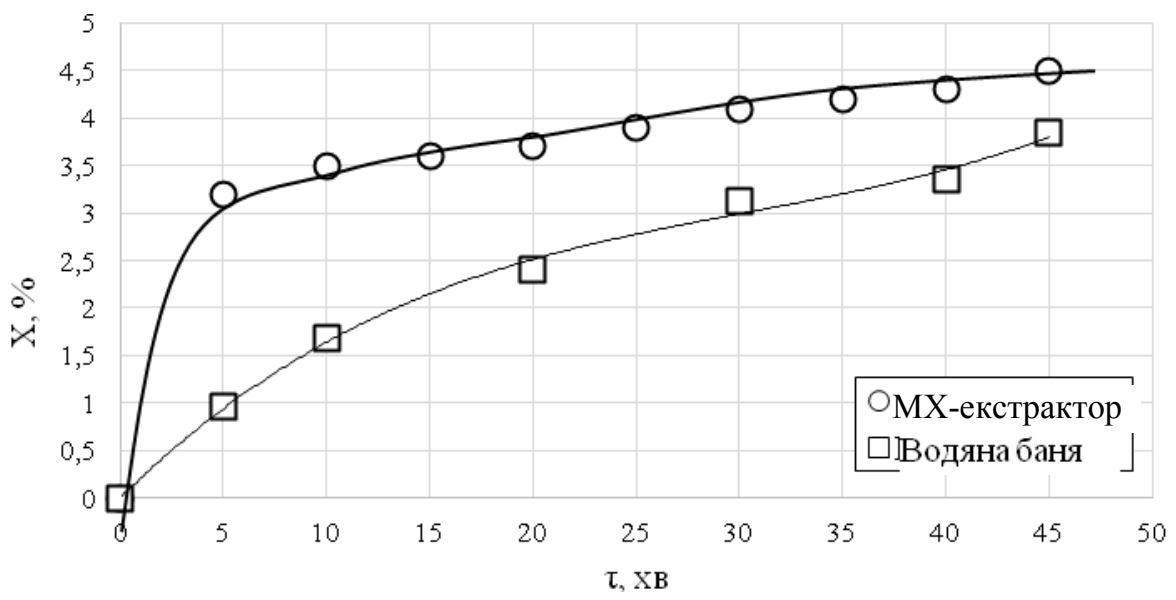

Рис. 4 - Порівняння зміни концентрації в часі при екстрагуванні вихідної сировини двома методами за першим заливом

Очевидний ефект застосування мікрохвильового поля для інтенсифікації процесу. 3 графіків випливає, що концентрація, якої досяг розчин при традиційному підведенні енергії за 45 хвилин, в умовах адресної доставки енергії досягається приблизно за 20 хвилин, тобто тривалість процесу може бути зменшена більш ніж в два рази.

В результаті хроматографічного дослідження одержаних водних екстрактів кавового лушпиння встановлено, що вміст кофеїну в них сягає $4,9 \%$ вилучених сухих речовин, олії - до $0,8 \%$.

Висновки. Задачі ефективної переробки рослинної сировини з одержанням цінних традиційних та нових продуктів, а також вилучення біологічно активних компонентів з відходів харчової промисловості рослинного походження запропоновано вирішувати із залученням мікрохвильових технологій в комбінації $з$ вакуумом. Такий підхід дозволяє не тільки ініціювати бародифузійні процеси в структурах сировини, але й суттєво знизити температуру обробки, зберігаючи термолабільні компоненти в кінцевому продукті. Крім того, частково вилучаються нерозчинні у екстрагенті, що використовується (вода), речовини: олії, ефірні олії. Показано значне скорочення тривалості процесу екстрагування у мікрохвильовому вакуум-екстракторі в 
Одеська національна академія харчових технологій

\section{ЕНЕРГОЕФЕКТИВНІСТЬ. РЕСУРСОЗБЕРІГАЮЧІ ТА ЕКОЛОГІЧНО-БЕЗПЕЧНІ} ЕНЕРГОТЕХНОЛОГІї

порівнянні з традиційним обладнанням. При концентруванні екстрактів лікарської та ефіроолійної сировини шляхом дистиляції в мікрохвильовому вакуум-випарному апараті одержано концентрати з високим вмістом сухих речовин (до 40\%), а також гідролати та ефірні олії м’яти та лаванди.

\section{References}

1. Ponomareva, E.I., Molokhova, E.I., Kholov, A.K. (2015) Primeneniye efirnykh masel v farmatsii. Sovremennyye problemy nauki $i$ obrazovaniya, 4. Retrieved from http://scienceeducation.ru/ru/article/view?id=21156

2. Stoyanova, A., Balinova-Tsvetkova, A. (2000). Tekhnologiya ekstraktov iz lavandy dlya kosmetiki. Izves-tiya vuzov. Pishchevaya tekhnologiya, 4, 63-66

3. Hosni, Karim \& Amel, Kerkenni \& Wafa, Medfei \& Brahim, Nadia \& Houcine, Sebei. (2010). Volatile Oil Constituents of Rosa canina L.: Quality As Affected by the Distillation Method. Organic Chemistry International. doi: 10.1155/2010/621967

4. Sidorov, I.I. (1984).Tekhnologiya natural'nykh efirnykh masel i sinteticheskikh dushistykh veshchestv, Moskva: Legkaya i pishchevaya prom-st'.

5. Rovná, Katarína \& Petrová, Jana \& Terentjeva, Margarita \& Černá, Jana \& Kacaniova, Miroslava. (2015). Antimicrobial activity of rosa canina flowers against selected microorganisms. Journal of Microbiology, Biotechnology and Food Sciences, 4. 62-64. doi:10.15414/jmbfs.2015.4.special1.62-64.

6. Vinokur, Yakov \& Rodov, Victor \& Reznick, Natalie \& Goldman, Genady \& Horev, Batia \& Umiel, Nakdimon \& Friedman, Haya. (2006). Rose Petal Tea as an Antioxidant-rich Beverage: Cultivar Effects. Journal of Food Science, 71. 42 - 47. doi: 10.1111/j.1365-2621.2006.tb12404.x.

7. Fatiha Brahmi, Madani Khodir, Chibane Mohamed and Duez Pierre (2017). Chemical Composition and Biological Activities of Mentha Species, Aromatic and Medicinal Plants. Back to Nature, Hany A. El-Shemy, IntechOpen, doi: 10.5772/67291. Available from: https://www.intechopen.com/books/aromatic-and-medicinalplants-back-to-nature/chemical-composition-and-biological-activities-of-mentha-species

8. Siddeeg, Azhari \& Salih, Zakaria \& Mukhtar, Rabab \& Ali, Ali. (2018). Extraction and Characterization of Peppermint (Mentha piperita) Essential Oil and its Assessment as Antioxidant and Antibacterial. Gezira Journal of Engineering and Applied Sciences, 13(1), 1-15.

9. Çam, M., Yüksel, E., Alaşalvar, H., Başyiğit, B., Şen, H., Yılmaztekin, M., Ahhmed, A., \& Sağdıç, O. (2019). Simultaneous extraction of phenolics and essential oil from peppermint by pressurized hot water extraction. Journal of food science and technology, 56(1), 200-207. doi:10.1007/s13197-018-3475-5

10. Timoshin, L.G., Efremov, A.A. (2007). Ispol'zovaniye myaty perechnoy i badana tolstolistnogo dlya polucheniya napitkov funktsional'nogo deystviya. Khimiya rastitel'nogo syr'ya, 4, 123-124.

11. Oliveira, L. S., \& Franca, A. S. (2015). An Overview of the Potential Uses for Coffee Husks. Coffee in Health and Disease Prevention, 283-291. doi:10.1016/b978-0-12-409517-5.00031-0

12. Klingel, T., Kremer, J. I., Gottstein, V., Rajcic de Rezende, T., Schwarz, S., \& Lachenmeier, D. W. (2020). A Review of Coffee By-Products Including Leaf, Flower, Cherry, Husk, Silver Skin, and Spent Grounds as Novel Foods within the European Union. Foods (Basel, Switzerland), 9(5), 665. https://doi.org/10.3390/foods9050665

13. Lund, D. (1988) Effects of Heat Processing on Nutrients. In: Karmas, E., Harris, R.S. (eds) Nutritional Evaluation of Food Processing (pp. 319-354). Springer, Dordrecht. https://doi.org/10.1007/978-94-011-7030-7_12

14. Burdo, O. G., Zykov, A. V., Terziev, S. G., \& Ruzhitskaya, N. V. (2016). The Nanotechnological Innovation in Food Industry. International Journal of Engineering Research and Applications (IJERA), 6(3), 144-150.

15. Burdo, O. G., Bandura, V. N., Yarovoy, I. I., \& Ruzhitskaya, N. V. (2011). Food nanotechnologies. Specificity and development directions. In VIII Minsk International Seminar "Heat Pipes, Heat Pumps, Refrigerators, Power Sourses, 155-160.

Отримано в редакцію 01.07.2020

Прийнято до друку 29.10.2020
Received 01.07.2020

Approved 29.10.2020 